\title{
Antiproliferative and antibacterial potential of tetrahexylammonium bromide-based ionic liquids
}

\author{
ROXANA POPESCU ${ }^{1,2^{*}}$, MARIOARA NICOLETA FILIMON ${ }^{2,3^{*}}$, DALIBORCA CRISTINA VLAD ${ }^{1}$, \\ DOINA VERDES ${ }^{1,2}$, AURICA MOATAR ${ }^{1}$, GEORGIANA MOISE ${ }^{1}$, KRISTINE GURAN ${ }^{1}$, \\ ION VALERIU CARABA ${ }^{4}$, LILIANA PETCULESCU CIOCHINA ${ }^{4}$, IULIA PINZARU ${ }^{5 *}$, \\ CRISTINA ADRIANA DEHELEAN ${ }^{5}$ and GABI DUMITRESCU ${ }^{2,4}$
}

\author{
${ }^{1}$ Faculty of Medicine; ${ }^{2}$ ANAPATMOL Research Center, 'Victor Babes' University of Medicine and \\ Pharmacy of Timisoara, 300041 Timisoara; ${ }^{3}$ Faculty of Chemistry, Biology, Geography, \\ West University of Timisoara, 300115 Timisoara; ${ }^{4}$ Faculty of Bioengineering of Animal Resources, \\ 'Regele Mihai I al României’ Banat University of Agricultural Sciences and Veterinary Medicine, 300645 Timisoara; \\ ${ }^{5}$ Faculty of Pharmacy, 'Victor Babes' University of Medicine and Pharmacy of Timisoara,
}

300041 Timisoara, Romania

Received February 12, 2021; Accepted March 16, 2021

DOI: $10.3892 / \mathrm{etm} .2021 .10104$

\begin{abstract}
Ionic liquids (ILs) exhibit cytotoxic effects on prokaryotic and eukaryotic cells. In this study, the antibacterial and antiproliferative activities of tetrahexylammonium bromide-based ILs were investigated. In order to evaluate the therapeutic potential of these ionic liquids, firstly microbiological assay using both Gram-positive and Gram-negative bacteria were conducted by employing Disk-Diffusion and 2,3,5-triphenyltetrazolium chlorine (TTC) methods to assess the antimicrobial effects. Likewise, the antitumor effects on $2 \mathrm{D}$ and $3 \mathrm{D}$ cell culture systems were assessed using the human colon cancer Caco-2 cell line and cytotoxic activity was assessed using 3-(4,5-dimethylthiazol-2-yl)-2,5-diphenyltetrazolium bromide (MTT) and Alamar blue assays. Results obtained showed that $\left[\mathrm{CH}_{3}\left(\mathrm{CH}_{2}\right)_{5}\right]_{4} \mathrm{~N}(\mathrm{Br})$ possesses an antibacterial potential, particularly in the case of two bacteria, $S$. aureus $\left(\mathrm{Gram}^{+}\right)$and $H$. influenzae $\left(\mathrm{Gram}^{-}\right)$. Preliminary screening of antiproliferative activity showed moderate activity, except for the concentration of $10 \mathrm{mM}$. Furthermore, regarding the effect of $\left[\mathrm{CH}_{3}\left(\mathrm{CH}_{2}\right)_{5}\right]_{4} \mathrm{~N}(\mathrm{Br})$ on tumor cell aggregation, positive outcomes were noted. $\left[\mathrm{CH}_{3}\left(\mathrm{CH}_{2}\right)_{5}\right]_{4} \mathrm{~N}(\mathrm{Br})$ presents promising
\end{abstract}

Correspondence to: Dr Marioara Nicoleta Filimon, ANAPATMOL Research Center, 'Victor Babes' University of Medicine and Pharmacy of Timisoara, 2 Eftimie Murgu Square, 300041 Timisoara, Romania

E-mail: marioara.filimon@e-uvt.ro

*Contributed equally

Key words: antiproliferative, antibacterial, tetrahexylammonium bromide-based ionic liquid, ionic liquids and under-explored potential to improve antibacterial or anticancer therapies.

\section{Introduction}

Ionic liquids (ILs) are a class of compounds of great importance in modern science due to their extensive use in major areas of research activity. For example, these liquids can be used as: i) alternative solvents to volatile organic compounds $(1,2)$, ii) media for electrodeposition of metals (3), iii) catalysts and biocatalysts $(4,5)$, iv) potential corrosion inhibitors $(6,7)$, or v) solvents in the food industry (8). ILs have several key physicochemical properties for such applications, including: high thermal stability, increased ionic conductivity, low vapor pressure, non-flammability, tenability and high polarity (9). As a result, they have attracted increasing research interest from the pharmaceutical industry.

ILs can affect biological systems at different biochemical levels, starting from simple macromolecules to complex metabolic mechanisms in prokaryotic and eukaryotic cells. In this context, investigation into the antimicrobial activity of different ILs classes on microorganisms of clinical and environmental importance has emerged as an important direction of research during the past few decades. Recent studies have shown that many types of ILs have the potential to inhibit the growth of different bacteria and fungi, rendering them useful for various applications in medicine and industry $(1,10,11-13)$. It has also been reported that antimicrobial activity is linked to the length of the substituent chain, with the mention that short-chain compounds exert a weaker antimicrobial efficacy compared to long-chain compounds (14-16). This antimicrobial effect was studied on both standardized bacterial strains and bacterial strains isolated from the hospital environment, and some of the strains of interest were found to display antibiotic resistance $(17,18)$. However, to fully evaluate the 
clinical applicability of ILs, further studies are required; one important topic being the deciphering of the toxicological, antimicrobial and antiproliferative effect of ILs.

The cytotoxicity of ILs has been extensively analyzed using in vitro $2 \mathrm{D}$ monolayer culture systems and different cell lines as study systems-both normal cells (fibroblasts, osteoblasts, macrophages, keratinocytes, rat glial cells) and neoplastic cell lines (breast, colon, lung, liver carcinoma and leukemia cells) (19). However, our knowledge concerning the possibility of using ILs as anticancer agents is yet to be fully understood. In addition, the use of the aforementioned culture systems has several drawbacks which may lead to the obtaining of unrealistic results. Thus, the substance of interest is applied in a uniform layer to the surface of the $2 \mathrm{D}$ culture. This contrasts with the three-dimensional architecture of tumors in vivo and also with the heterogeneous distribution of nutrients and drugs in tumor cells. This environment can more realistically be replicated via the use of an in vitro 3D culture, which generates multilayer cell aggregates with a complex tissue organization, similar to what can be observed in vivo (20).

The present study was designed to investigate the antibacterial and antiproliferative effect of tetrahexylammonium bromide (THABr) ionic liquid formulation. To evaluate the antibacterial effect of THABr_IL, the following standardized bacterial strains were used: i) Gram-positive bacteria $\left(\mathrm{Gram}^{+}\right)$: Staphylococcus aureus, Streptococcus pneumoniae and Enterococcus faecalis; and ii) Gram-negative bacteria (Gram-): Escherichia coli, Salmonella typhimurium, Proteus miriabilis, Klebsiella pneumoniae, Pseudomonas aeruginosa and Haemphilus influenzae. The cell line Caco-2 (colorectal adenocarcinoma) served as a study system and was grown in vitro using both $2 \mathrm{D}$ and $3 \mathrm{D}$ culture systems.

\section{Materials and methods}

Tetrahexylammonium bromide $\left[\mathrm{CH}_{3}\left(\mathrm{CH}_{2}\right)_{5}\right]_{4} \mathrm{~N}(\mathrm{Br})$ and distilled water were purchased from Sigma-Aldrich (Merck $\mathrm{KGaA}$ ). Cell culture specific reagents [Dulbecco's modified Eagle's medium (DMEM), fetal bovine serum (FBS), dimethyl sulfoxide (DMSO), trypsin-EDTA solution, penicillinstreptomycin mixture, and phosphate-buffered saline (DMSO)] and cytotoxicity assays [3-(4,5-dimethylthiazol2-yl)-2,5-diphenyltetrazolium bromide (MTT) and Alamar blue] were obtained from Invitrogen (Thermo Fisher Scientific, Inc.).

\section{Antimicrobial susceptibility tests}

Microorganism testing. The antimicrobial activity was studied for $\mathrm{Gram}^{+}$bacteria, represented by Staphylococcus aureus (ATCC 25923), Streptococcus pneumoniae (ATCC 49619) and Enterococcus faecalis (ATCC 29212) and Gram bacteria, represented by Escherichia coli (ATCC 25922), Salmonella typhimurium (ATCC 14028), Proteus miriabilis (ATCC 12453), Klebsiella pneumoniae (ATCC 1388), Pseudomonas aeruginosa (ATCC 27853) and Haemphilus influenzae (ATCC 49247). The tested THAB_IL concentrations were: $\mathrm{c} 1,13.6 \mathrm{mg} / \mathrm{ml}$; 2 , $6.8 \mathrm{mg} / \mathrm{ml} ; \mathrm{c} 3,3.4 \mathrm{mg} / \mathrm{ml}$; $4,1.7 \mathrm{mg} / \mathrm{ml}$; and $\mathrm{c} 5,0.85 \mathrm{mg} / \mathrm{ml}$. Concentrations of interest were prepared using sterile distilled water.
Determination of the minimum inhibitory concentration $(M I C)$. Antimicrobial tests (antibiogram and ionic liquid testing) for the microorganisms studied were carried out using the Disk Diffusion method as previously described (21). A small amount of each microbial culture was diluted in sterile $0.9 \%$ sodium chloride solution until the turbidity was equivalent to the $0.5 \mathrm{McFarland}$ standard. These suspensions were further diluted 1:10 in medium CHROM agar for bacteria (Oxoid) and then spread on sterile Petri plates. Sterile micro-compresses were applied on the agar surface (in Petri plates), and after that $10 \mu \mathrm{l}$ of each sample was added into the micro-compresses. Commercially available discs containing antibiotics were used as positive controls. The plates were incubated at $37^{\circ} \mathrm{C}$ for $24 \mathrm{~h}$.

The inhibition zones were assessed by comparatively testing THABr_IL vs. gentamicin $(\mathrm{Gn})$ and THABr_IL vs. trimethoprim/sulfamethoxazole (Sxt). Gentamycin and trimethoprim/sulfamethoxazole were used as controls for $\mathrm{Gram}^{+}$and Gram bacteria, respectively.

Cellular viability test from bacterial strain. An amount $100 \mu \mathrm{l}$ of microbial cultures in Mueller Hinton broth (with a turbidity was equivalent to $0.5 \mathrm{McF}$ arland standard) was transferred into 96-well plates. Next, $50 \mu \mathrm{l}$ THABr_IL at different concentrations of interest were loaded into wells-with Sxt and Gn used as controls- and the plates were incubated at $37^{\circ} \mathrm{C}$ for $6 \mathrm{~h}$. After adding $10 \mu \mathrm{l}$ of solution of 2,3,5-tripheniltetrazolium chlorine $0.5 \%$ (TTC) into the wells, the plates were incubated at $37^{\circ} \mathrm{C}$ for another $2 \mathrm{~h}$. Absorbance was measured at $460 \mathrm{~nm}$ (Tecan Sunrise spectrophotometer). The rate of inhibition (expressed as a percentage) was determined as the ratio between the difference between absorbance values of the control and sample and absorbance value of the control. All experiments were conducted in triplicate.

\section{In vitro cytotoxicity testing}

$2 D$ cell culture. Human colon adenocarcinoma Caco-2 cells (ATCC ${ }^{\circledR}$ HTB-37 ${ }^{\mathrm{TM}}$ ) were used as a cell line model. Briefly, the cells were seeded in $75 \mathrm{~cm}^{2}$ flasks in DMEM GlutaMax medium supplemented with $10 \%$ FBS and antibiotics in a $5 \%$ humidified atmosphere at $37^{\circ} \mathrm{C}$. At $80-90 \%$ confluence, the Caco-2 cells were detached by trypsinization, and the cell number was assessed using the Countess II Automated Cell Counter (Thermo Fisher Scientific, Inc.). Caco-2 cells (100 $\mu 1,2 \times 10^{5}$ cells $\left./ \mathrm{ml}\right)$ were next seeded in a 96-well plate. After $12 \mathrm{~h}$, fresh complete medium containing different concentration of THABr_IL dissolved in DMSO (ranging from 0.1 to $10 \mathrm{mM}$ ) was added, with $0.1 \%$ DMSO being used as vehicle control. The cytotoxic effect was assessed with MTT reagent. After 24,48 or $72 \mathrm{~h}$, MTT solution $(5 \mathrm{mg} / \mathrm{ml}$ in PBS) was added, followed by incubation at $37^{\circ} \mathrm{C}$ for $4 \mathrm{~h}$. Then the medium was removed and $50 \mu 1 \mathrm{DMSO}$ was added to solubilize the formazan crystals. The absorbance was read at $570 \mathrm{~nm}$ (Tecan Sunrise spectrophotometer). The cells treated only with DMSO (0.1\%) were used as control to calculate the inhibition rate (\%) as described above. All experiments were run in triplicate.

\section{$3 D$ cell culture}

Development of $3 D$ cellular aggregates. A total of $1 \times 10^{4}$ cells $/ \mathrm{ml}$ in $100 \mu \mathrm{l}$ medium $\left(1 \times 10^{3}\right.$ cells/well) were seeded 
in 96-well plates (NunclonSphera, Thermo Fisher Scientific, Inc.). After $72 \mathrm{~h}$ and after adding fresh specific medium with different concentrations of THABr_IL or $0.1 \%$ DMSO, the plates were maintained in an incubator at $37^{\circ} \mathrm{C}$ with $5 \% \mathrm{CO}_{2}$ for 24 and $72 \mathrm{~h}$. The Alamar blue assay was used to assess the effects of THABr_IL on Caco-2 cell viability and proliferation. Alamar blue reagent $[10 \%(\mathrm{v} / \mathrm{v})]$ was added in each well, and then the absorbance was measured at 570 and $600 \mathrm{~nm}$ (Tecan Sunrise spectrophotometer) to calculate cell proliferation. Cell morphology was analyzed by using a Zeiss Axio Observer A1 Inverted Phase Contrast Microscope (Zeiss).

Statistical analyses. Statistical analyses were performed using Excel from MS Office Pro Plus 2019 and GraphPad Prism 8 (GraphPad Software, Inc.); the differences were assessed by one-way ANOVA. The level of $\mathrm{P}<0.1$ was considered statistically significant and $\mathrm{P} \leq 0.0001$ was considered highly statistically significant. The following notations were used on the graphs: ${ }^{*} \mathrm{P} \leq 0.1,{ }^{* *} \mathrm{P} \leq 0.01,{ }^{* * *} \mathrm{P} \leq 0.001$ and ${ }^{* * * *} \mathrm{P} \leq 0.0001$.

\section{Results}

Antimicrobial activity. The antimicrobial effect of tetrahexylammonium bromide (as IL) on three different $\mathrm{Gram}^{+}$bacteria was investigated. The growth of $S$. aureus was affected by all five tested concentrations, while the corresponding diameter of the zone of inhibition was recorded between 10 and $12.75 \mathrm{~mm}$. This indicates a moderate antibacterial effect of tetrahexylammonium bromide on the aforementioned bacterial strain. In the case of E. faecalis, this antibacterial effect was pronounced only for the highest concentrations tested (c1-c3) and in the case of S. pneumoniae, this effect occurred at c1-c4 concentrations tested (Fig. 1A).

In contrast to $\mathrm{Gram}^{+}$bacteria, a quite homogenous pattern of response to tetrahexylammonium bromide exposure was found in the Gram bacteria, with E. coli, S. typhimurium and $K$. pneumoniae showing an intermediate sensitivity to this THABr_IL formulation. These bacteria were inhibited when exposed to the three highest concentrations, but were not affected by the two lowest doses. Concerning P. mirabilis and $P$. aeruginosa, the measured values of the inhibition areas were between 9.85-10.75 and 8.75-11 mm, respectively, again with an inhibitory effect being detected at the highest treatment doses. The strongest antibacterial activity of this THABr_IL formulation was identified for $H$. influenzae, with a diameter of zone of inhibition around 11-13 mm (Fig. 1B).

The diameters of the corresponding zones of inhibition were $15 \mathrm{~mm}$ (for gn) and $17 \mathrm{~mm}$ (for Sxt). Compared with standard reference antibiotics (gn and Sxt), tetrahexylammonium bromide (as IL) exerted a weaker antimicrobial effect expressed by smaller inhibition areas. These changes were found to be statistically significant $(\mathrm{P}<0.1, \mathrm{P}<0.01, \mathrm{P}<0.001)$, but this antimicrobial effect was found to vary depending on the tested concentration and bacteria (Fig. 1).

Concerning the rate of inhibition (\%) of $\mathrm{Gram}^{+}$bacteria, the measured values ranged between 68.80 and $76.08 \%$ for S. aureus; between 46.98 and $80.47 \%$ for S. pneumoniae; and between 37.63 and $73.11 \%$ for E. faecalis. A clear bacteriolytic activity of tetrahexylammonium bromide was identified for all concentrations tested, the highest four concentrations and the highest three concentrations for $S$. aureus, $S$. pneumoniae and E. faecalis, respectively (Fig. 2A).

In the case of $\mathrm{Gram}^{-}$bacteria, the measured rates of inhibition were also diferent among bacteria and treatment groups. Thus, the bacteriolytic potential against E. coli, K. pneumoniae, $P$. mirabilis and $P$. aeruginosa was observed when these bacteria where exposed to the highest three tetrahexylammonium bromide concentrations. For S. typhimurium, by contrast, this potential was noted only for the highest two treatment groups. In the case of $H$. influenzae, the rates of inhibition were $82.01-84.70 \%$, with the tested IL showing a bacteriolytic action for all analyzed doses (Fig. 2B).

Cytotoxic capacity. The density of cultured cells was 4,000 cells/well for the 3D cell culture and 20,000 cells/well for the 2D cell culture. Determination of the antiproliferative potential was performed by incubating cells in specific media containing different concentrations of tetrahexylammonium bromide in DMSO. First, the IL was solubilized in DMSO (stock solution), and then the final concentrations (10, $5,1,0.5$ and $0.1 \mathrm{mM}$ ) were obtained by dilution in culture medium. The concentration of DMSO in culture medium was $0.1 \%$, a concentration at which cell viability is not affected. After one day of incubation, the 2D cell cultures revealed a slight decrease in cell proliferation. However, the inhibition rate was dose-dependent, with statistically significant differences $(\mathrm{P} \leq 0.01)$ being observed between different treatments. The half maximal inhibitory concentration $\left(\mathrm{IC}_{50}\right)$ was not reached, irrespective of the tested concentrations and bacterial strain. More than half of cells showed reduced growth following 48 and $72 \mathrm{~h}$ of continuous exposure to $10 \mathrm{mM}$ tetrahexylammonium bromide, more precisely 55.57 and $60.26 \%$ at 48 and 72 h, respectively (Fig. 3). Exposure of Caco- 2 cells to the THABr_IL resulted in significantly different cellular responses between the $10 \mathrm{mM}$ treatment and the other treatments used. Were also noticed a similar pattern for the $0.5 \mathrm{mM}$ treatment and the $1 \mathrm{mM}$ treatment $(\mathrm{P} \leq 0.0001)$.

Assessment of tetrahexylammonium bromide effect on 3D culture neoplastic colon cells was conducted after exposing the cells to THABr_IL at different concentrations for $72 \mathrm{~h}$. Aiming to create optimal conditions for the development of cell aggregates, the cells were first cultured in a specific medium without IL for 4 days (Fig. 4).

Evaluation of morphology of mature cellular aggregates was performed at 7 days, while 0.1\% DMSO was used as reference. It was observed that the cell aggregates in the control groups tended to have round/oval shape. In contrast, cell cultures exposed to tetrahexylammonium bromide showed alterations in cell shape and dimensions. In fact, none of the cells from these treatment groups had a round shape, which is characteristic to spheroids in the control group. In addition, at high IL doses the formation of multiple, uneven cellular aggregates was observed (Fig. 5).

Analysis of the cell proliferation using the Alamar blue test also revealed no consistent effect on cell proliferation in the exposed groups. Inhibition of cell multiplication appeared to be independent of tetrahexylammonium bromide dose and ranged from $31.01 \%$ (0.5 $\mathrm{mM}$ concentration) to $25.33 \%$ (1 $\mathrm{mM}$ concentration). 
A 18
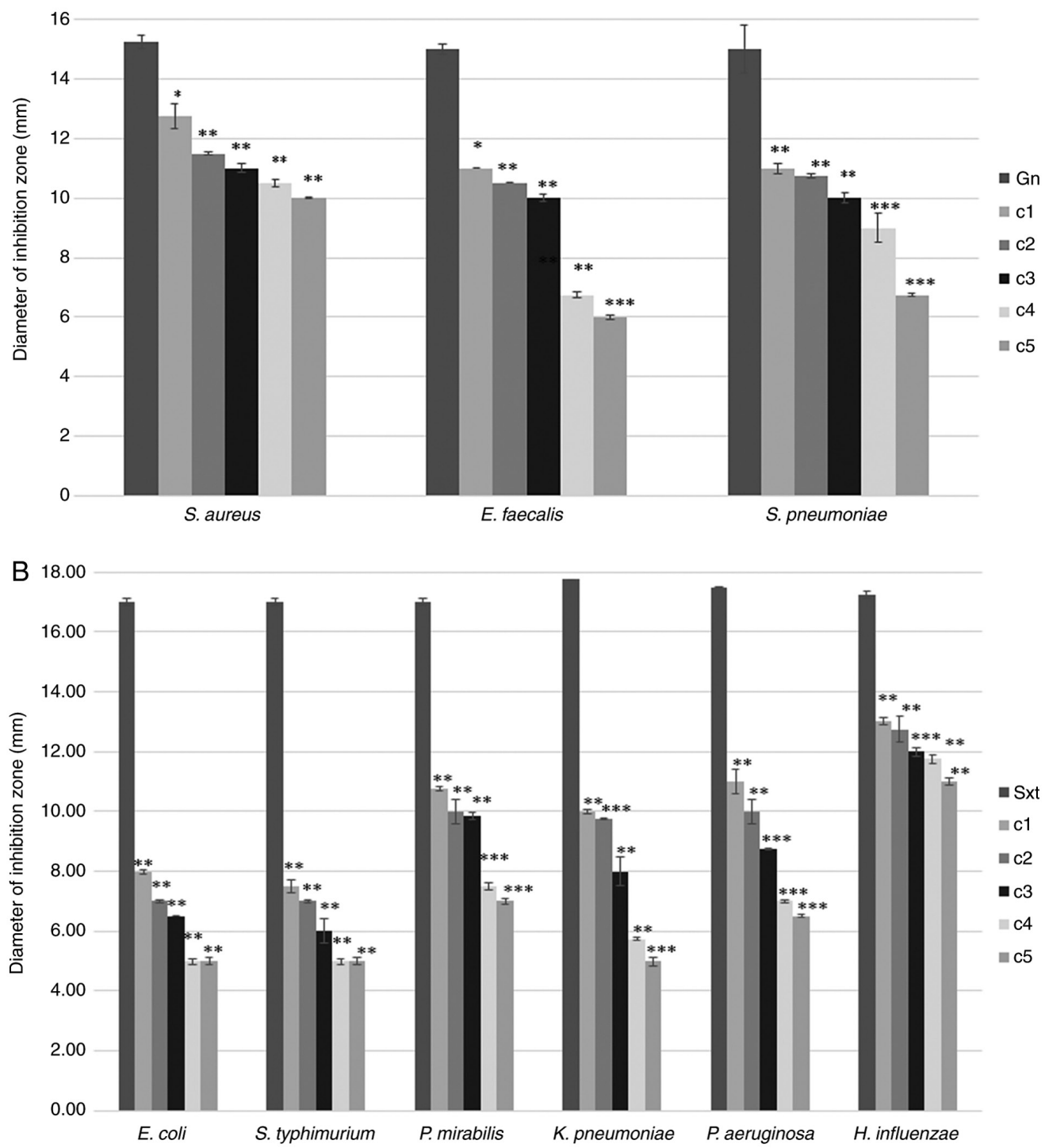

Figure 1. The diameter of the zone of inhibition in different bacterial strains exposed to tetrahexylammonium bromide ionic liquid (THAB_IL).(A) Gram-positive bacteria, (B) Gram-negative bacteria. The tested tetrahexylammonium bromide (THAB_IL) concentrations were: c1, $13.6 \mathrm{mg} / \mathrm{ml} ; \mathrm{c} 2,6.8 \mathrm{mg} / \mathrm{ml} ; \mathrm{c} 3,3.4 \mathrm{mg} / \mathrm{ml}$; $\mathrm{c} 4,1.7 \mathrm{mg} / \mathrm{ml}$; and c5, $0.85 \mathrm{mg} / \mathrm{ml}$. Gn-gentamicin; Sxt-trimethoprim/sulfamethoxazole $\left({ }^{*} \mathrm{P}<0.1,{ }^{* *} \mathrm{P}<0.01,{ }^{* * *} \mathrm{P}<0.001\right)$.

In the cells cultured in the 3D system, THABr_IL did not cause an increased inhibition of cell growth $\left(\mathrm{IC}_{50}\right.$ was not reached at any applied concentration), however, this ionic fluid appeared to inhibit cell aggregation in the 3D structures.

\section{Discussion}

To the best of our knowledge, in vitro cytotoxicity studies for ionic liquids (ILs) have been performed only using 2D cell cultures. This is hence the first study to use 3D-cultured cells to study the cytotoxic effect of tetrahexylammonium bromide, an IL. By using a comparative approach, our paper also extends from a bidirectional point of view the previous knowledge existing on the potential clinical importance of these compounds. The biological activity of ILs depends primarily on their hydration status $(22,23)$; although their mechanisms of action can vary among different organisms, water being essential for all living systems. Therefore, the main factors modulating the biological activity of ILs are their solubility and their interaction with water (24). These liquids can dissolve a wide array of chemical compounds (25) and many of them can act against cell systems. Various ILs are highly toxic for cellular systems and can induce changes in intracellular osmotic pressure, structure alterations and fluidity of the cell membrane, as well as inhibition of enzymatic activity via changes in their folding. The dynamic interplay underlying such changes is now a subject of intense research interest (26).

There are many different mechanisms of action by which chemical compounds can affect bacterial cells, including protein denaturation, disruption of nucleo-protein complexes, cell membrane alteration, oxidation of sulph-hydryl groups and reactions with amino groups $(27,28)$. Our team has conducted studies regarding the therapeutic potential of some biologically active or synthetic compounds, including the chemical characterization of plant compounds, some of which have confirmed antitumor and antibacterial potential $(29,30)$. Certainly, the 

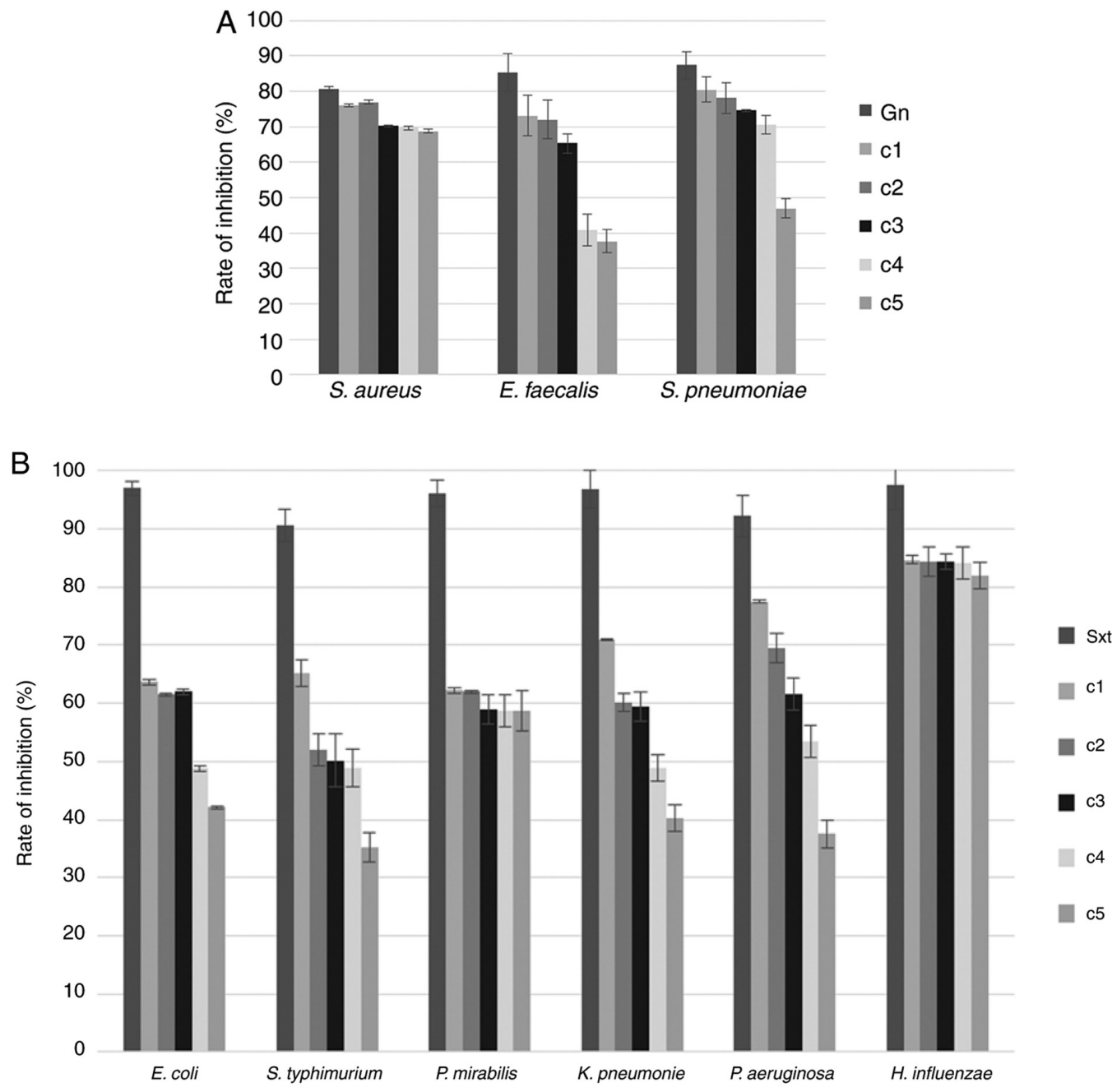

Figure 2. The rate of inhibition (\%) for bacterial strains exposed to tetrahexylammonium bromide ionic liquid (THAB_IL). (A) Gram-positive bacteria, (B) Gram-negative bacteria. The tested tetrahexylammonium bromide (THAB_IL) concentrations were: c1, $13.6 \mathrm{mg} / \mathrm{ml} ; \mathrm{c} 2,6.8 \mathrm{mg} / \mathrm{ml} ; \mathrm{c} 3,3.4 \mathrm{mg} / \mathrm{ml} ; \mathrm{c} 4$, $1.7 \mathrm{mg} / \mathrm{ml}$; and c5, $0.85 \mathrm{mg} / \mathrm{ml}$. Gn-gentamicin; Sxt-trimethoprim/sulfamethoxazole).

applicability of these compounds in medical practice requires additional studies on their physicochemical characterization, their bioavailability and other pharmacokinetic parameters. The antibacterial activity of ILs is based on the interaction of the alkyl chain with membrane lipids, leading to the formation of ion channels, disturbance of the corresponding transmembrane potential, and finally, to the death of bacteria $(31,32)$. Quaternary ammonium halides, which serve as precursors for ILs, exhibit notable antimicrobial properties. They have a relatively low toxicity to organisms and they are used in sterilization, disinfection, as well as in the preparation of compounds with bactericidal and fungicidal properties (33). Among this category of compounds, quaternary ammonium chlorides and bromides are the most frequently used quaternary ammonium halides as antiseptics despite having some potential drawbacks $(34,35)$.

Antimicrobial activity depends on the length and the number of alkyl chains within the molecule $(27,28,36)$. There is strong evidence that, for ILs containing methylimidazolium cation, the toxicity is mainly related to the length of the n-alkyl radical, but not to the anion type (37). Several studies have also demonstrated that compounds with an alkyl radical exceeding four carbon atoms exert marked toxic effects on different bacteria, such as Escherichia coli, Staphylococcus aureus and Bacillus subtilis, and prokaryotes, e.g. cladoceres such as Daphnia magna and green algae such as Oocystis submarina, Chlorella vulgaris, Scenedesmus vacuolatus and Chlamidomonas reinhardtii $(38,39)$.

The bactericidal activity of ILs is only known for vegetative forms of bacteria, with gram-positive bacteria being more sensitive than gram-negative. The strongest effect was identified to occur against gram-positive bacteria belonging to the genus Staphylococcus and Streptococcus, gram-negative bacteria belonging to the genus Lactobacillus and vegetative forms of Bacillus subtilis. The biological activity of ILs is high for compounds containing up to 12 carbon atoms (40). Moreover, certain yeasts, such as Candida albicans, and filamentous fungi (Aspergillus niger, Chaetomiumglobosum, Myrotheciumverrucaria, Trichodermaviridae, Coniophoraputean, Trametes versicolor) were found to be sensitive to exposure to quaternary ammonium halides (40). The incidence of infections and especially their recurrence, in most medical fields, with a maximum recorded in cases involving surgery, is increasing despite the constant improvement of treatment protocols (41). There are still a number of gaps and these new approaches send positive signals about the 


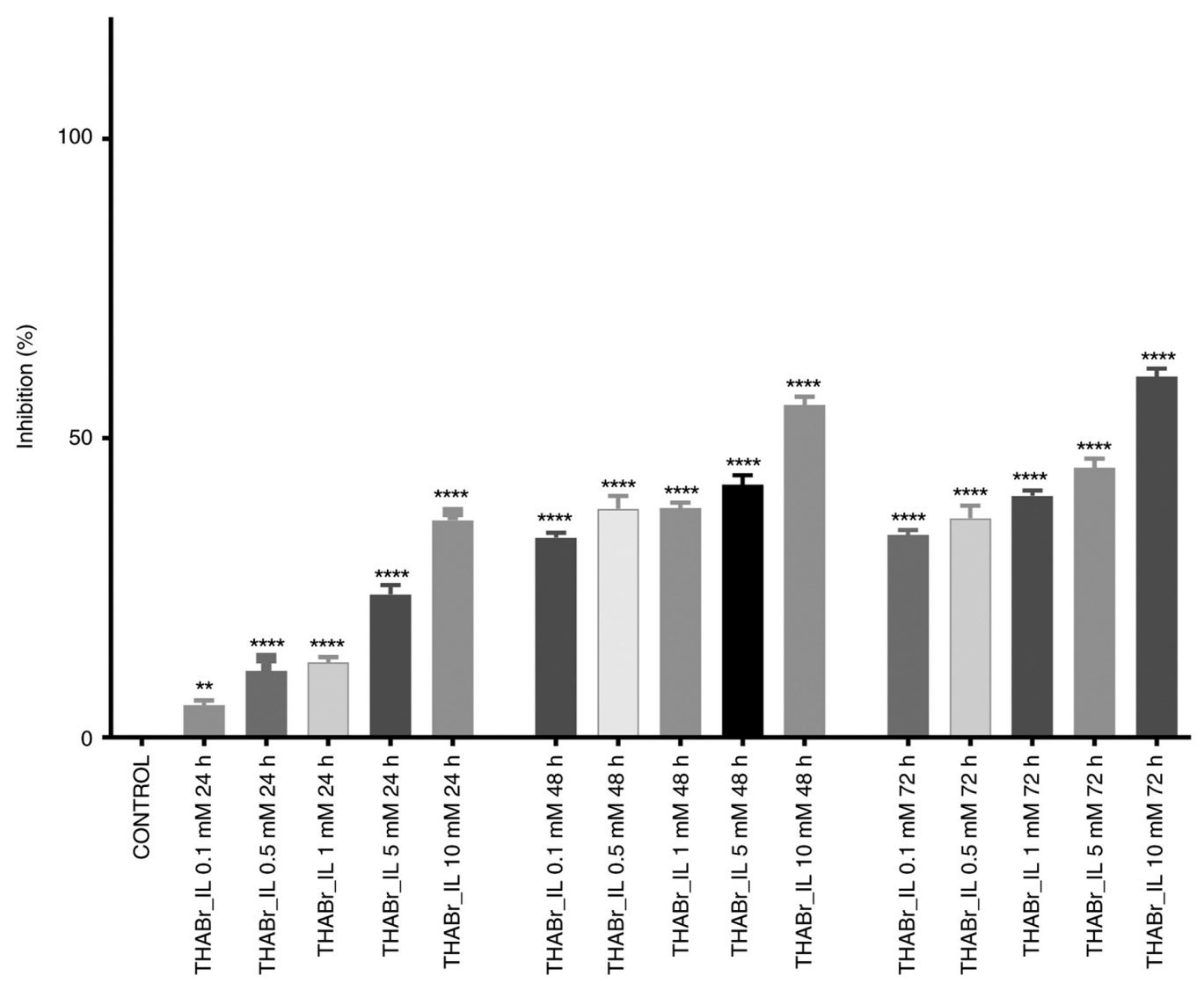

Figure 3. Caco-2 cell (2D cell culture) inhibition rate after tetrahexylammonium bromide ionic liquid (THAB_IL) treatment at different concentrations for 24, 48 and $72 \mathrm{~h}$. One-way ANOVA analysis followed by Dunnett's multiple comparisons post-test was utilized to detect the statistical differences between the control and the treated group $\left({ }^{* *} \mathrm{P}<0.01\right.$ and $\left.{ }^{* * * * *} \mathrm{P}<0.0001\right)$.

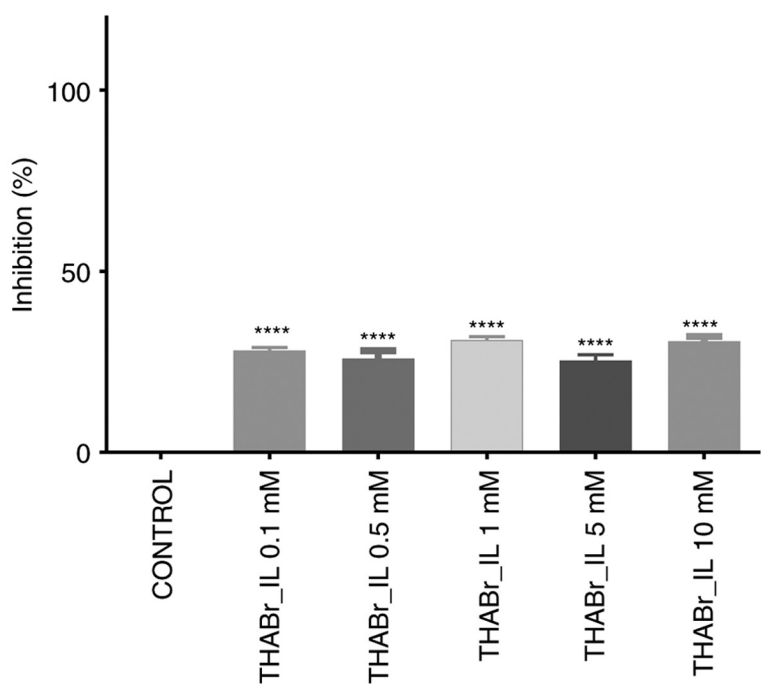

Figure 4. Caco-2 cell (3D cell culture) inhibition rate after tetrahexylammonium bromide ionic liquid (THAB_IL) treatment at different concentrations. One-way ANOVA analysis followed by Dunnett's multiple comparisons post-test was utilized to detect the statistical differences between the control and the treated group $\left({ }^{* * * *} \mathrm{P}<0.0001\right)$.

possibility of combating these deficiencies. Although many studies have been conducted over time on topics related to antimicrobial effect of different ILs $(17,18,42,43)$, the mechanisms underlying these effects or the clinical relevance of these results are still far from being completely understood.
Further studies are hence required, not only to expand on the clinical significance of the antibacterial effect of ILs, but also to refine our knowledge of how different ILs interact with different types of bacteria.

For in vitro evaluation of the cytotoxicity of ILs, cell lines of different organisms (humans, rats, mice, Chinese hamsters) have been utilized. Concerning the Caco-2 cell line (colorectal adenocarcinoma), ILs based on imidazolium, guanidinium, ammonium, phosphonium, pyridinium, pyrrolidinium and choline have been tested (44-47). To the best of our knowledge, in vitro cytotoxicity studies of ILs have been performed on 2D cell cultures The aim of our work was to evaluate the effect of different concentrations of tetrahexyl ammonium bromide on Caco-2 cells, seeded in 2D and 3D systems.

3D culture cell systems grow naturally in an environment allowing them to interact with each other, with MEC (microbial electrolysis cell) and their microenvironment. In turn, these interactions affect cell functioning, including cell proliferation, cell differentiation, cell morphology, gene expression, protein synthesis and cellular responses to external stimuli. Monolayer (2D) cell cultures consist of living, proliferating cells, as necrotic cells are usually detached from the surface of the monolayer and can be easily removed during change in cell media. Abnormal cell morphology in 2D culture also influences many of the aforementioned cellular processes. Despite these disadvantages, the $2 \mathrm{D}$ cell culture is still the most common in vitro testing platform. Unlike 2D culture, 3D culture cells form aggregates or spheroids on a matrix 

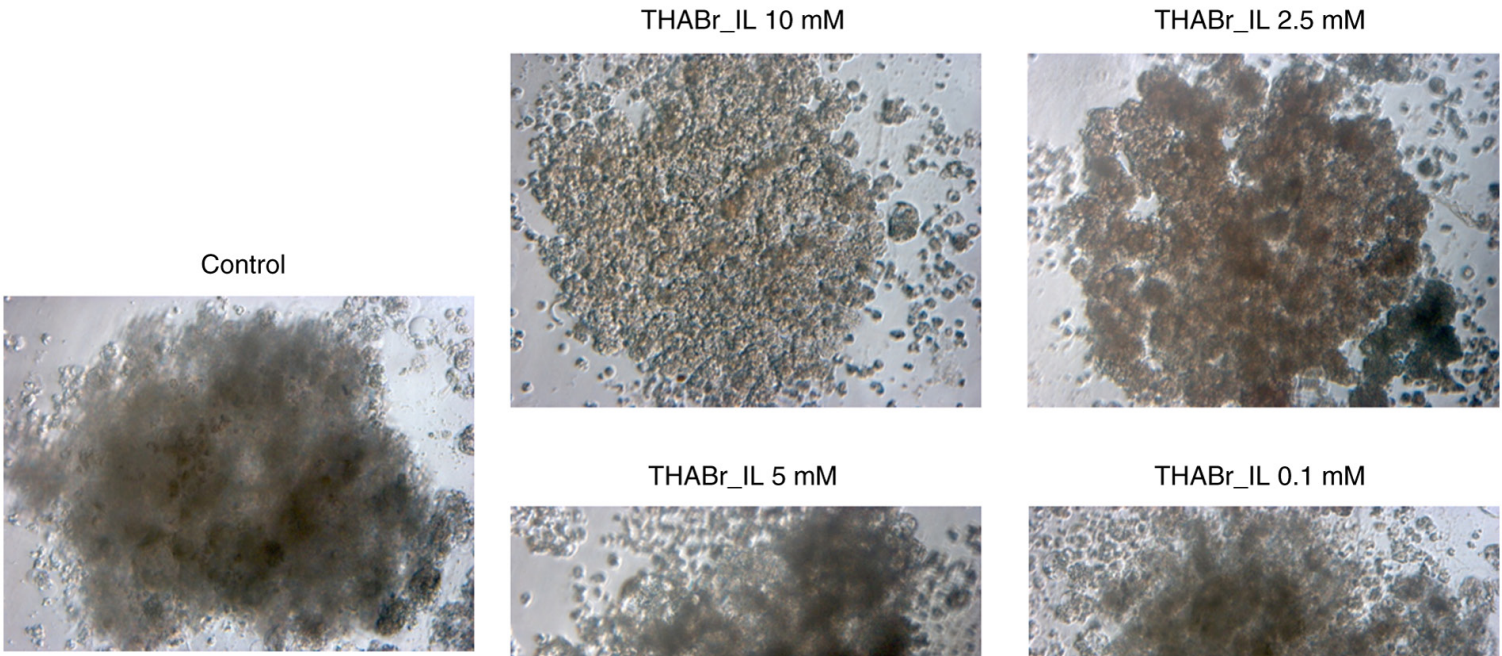

THABr_IL $5 \mathrm{mM}$

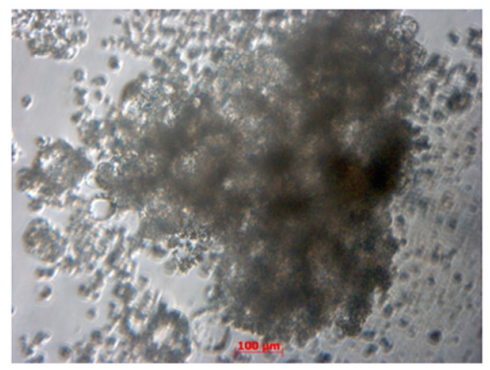

THABr_IL $0.1 \mathrm{mM}$

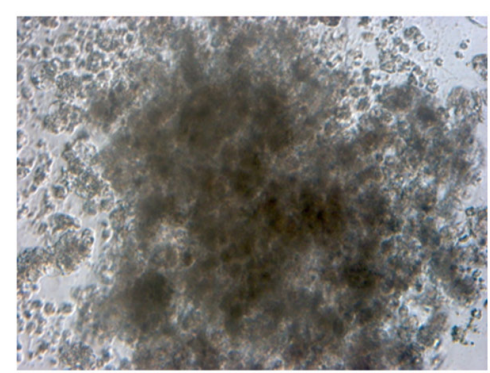

Figure 5. Mature cellular aggregate morphology of the different treatment groups. Control, Caco-2 cells seeded in a 3D plate; THABr_IL 10 mM, Caco-2 cells seeded in a 3D plate and treated with $10 \mathrm{mM}$ tetrahexylammonium bromide ionic liquid; THABr_IL 5 mM, Caco-2 cells seeded in 3D plate and treated with $5 \mathrm{mM}$ tetrahexylammonium bromide ionic liquid; THABr_IL $2.5 \mathrm{mM}$, Caco-2 cells seeded in 3D plate and treated with 2.5 mM tetrahexylammonium bromide ionic liquid; THABr_IL $0.1 \mathrm{mM}$, Caco-2 cells seeded in a 3D plate and treated with $0.1 \mathrm{mM}$ tetrahexylammonium bromide ionic liquid. Scale bar, $100 \mu \mathrm{m}$.

or while being suspended in growth medium. In cell aggregates, the cell-cell and cell-MEC interactions allow scientists to realistically replicate in vivo conditions. In addition, 3D constructs are composed of cells at various developmental stages, including proliferative cells, senescent cells, apoptotic cells, hypoxic cell, and necrotic cells. The outer layers of a spheroid, which is highly exposed to the environment, include mainly viable, proliferating cells. The heterogeneity of $3 \mathrm{D}$ cells is very similar to those seen in tissues in vivo, especially in tumors. In the present study, although the inhibition of proliferation in cells cultured in the 3D system was not significant compared to the control group, we observed an alteration in the shape of cell aggregates at high doses of the IL.

Several recent studies have reported that different types of ILs have antitumor potential. Various cell lines were used to assess the cytotoxic potential. For instance, Kumar and Malhotra evaluated the cytotoxic effect of ammonium and phosphonium-based ILs on 60 different cell lines. Their study showed that the length of the alkyl chain is directly related to antitumor and cytotoxic activity; the increase in the length of the alkyl chain being accompanied by an increase in antitumor activity. On the other hand, they reported that anions have a significant effect on cytotoxicity, while cations appear to play a major role in cytostatic activity. Ammonium-based ILs had a higher cytotoxic potential than those based on phosphonium (48). At present, the data reported by most studies indicate that the length of the carbon atom chain has a key role in the anticancer effect of ILs. In 2015, Li et al reported that imidazolium-based IL and bromide anion (1-methyl-3-octylimidazolium bromide) exert a cytotoxic action on HepG2 cells, inducing caspase-mediated apoptosis (49). As evidenced by the reported data, the presence of the bromide anion does not appear to influence the antitumor activity of ILs $(49,50)$. However, in some ILs, the anionic moiety influences the cytotoxic action $(44,51)$. The clinical future of these compounds looks promising. Formulations for topical application based on ILs have shown promising results in some in vivo tests and have even reached clinical trials $(52,53)$.

The antibacterial effect of the tetrahexylammonium bromide IL displayed variations depending on the tested concentrations and on the bacterial strain studied; in general the effect was highlighted when testing the highest concentrations (c1-c3). In the case of $\mathrm{Gram}^{+}$bacteria, the sensitivity to the tested IL decreased as follows: $S$. aureus $>$ S. pneumoniae $>$ E. faecalis. In $\mathrm{Gram}^{-}$bacterial strains, the antibacterial effect of the IL decreased as follows: $H$. influenzae $>P$. mirabilis $>$ $P$. aeruginosa $>$ K. pneumoniae $>E$. coli $>$ S. typhimurium . Regarding the cytotoxic potential on Caco-2 neoplastic colon cells, moderate results were noted. Future studies should be conducted to assess the impact of THABr_IL on a three-dimensional aggregation of tumor cells.

\section{Acknowledgements}

Not applicable.

\section{Funding}

No funding was received.

\section{Availability of data and materials}

Authors may make available to the publisher the data and materials presented in the manuscript. 


\section{Authors' contributions}

Conceptualization of the research study was achieved by RP, MNF and IP. Data curation was conducted by DCV, DV, KG and GD. Formal analysis was conducted by RP, AM, GM, LPC and GD. Funding acquisition was the responsibility of $\mathrm{RP}$ and DCV. Investigation was carried out by IVC, CAD, KG, AM and GM. Research methodology was the responsibility of MNF, IP, DV and IVC. Project administration was the responsibility of RP, MNF and GD. Resources were obtained by KG and LPC. Software was the responsibility of IP, CAD and DCV. Supervision was undertaken by RP, MNF, IP, and GD. Validation was carried out by DV, AM, CAD and GM. Visualization was undertaken by IVC, IP and LPC. Writing of the original draft was conducted by DCV, DV, KG and GM; writing, review and editing was conducted by IP, AM, IVC and CAD. All authors read and approved the final manuscript.

\section{Ethics approval and consent to participate}

The study respected norms of professional ethics and deontology.

\section{Patient consent for publication}

Not applicable.

\section{Competing interests}

The authors declare that they have no competing interests.

\section{References}

1. Busetti A, Crawford DE, Earle MJ, Gilea MA, Gilmore BF Gorman SP, Laverty G, Lowry AF, McLaughlin M and Seddon KR: Antimicrobial and antibiofilm activities of 1-alkylquinolinium bromide ionic liquids. Green Chem 12: 420-425, 2010.

2. Myles L, Gore R, Špulák M, Gathergood N and Connon SJ: Highly recyclable, imidazolium derived ionic liquids of low antimicrobial and antifungal toxicity: A new strategy for acid catalysis. Green Chem 12: 1157-1162, 2010.

3. Endres F: Ionic liquids: Solvents for the electrodeposition of metals and semiconductors. Chemphyschem 3: 144-154, 2002.

4. Moniruzzaman M, Nakashima K, Kamiya N and Goto M: Recent advances of enzymatic reactions in ionic liquids. Biochem Eng J 48: 295-314, 2010.

5. Ferlin N, Courty M, Gatard S, Spulak M, Quilty B, Beadham I, Ghavre M, Haiss A, Kümmerer K, Gathergood N and Bouquillon S: Biomass derived ionic liquids: Synthesis from natural organic acids, characterization, toxicity, biodegradation and use as solvents for catalytic hydrogenation processes. Tetrahedron 69: 6150-6161, 2013.

6. Messali M: A green microwave-assisted synthesis, characterization and comparative study of new pyridazinium-based ionic liquids derivatives towards corrosion of mild steel in acidic environment. J Mater Environ Sci 2: 174-185, 2011.

7. Messali M, Bousskri A, Anejjar A, Salghi R and Hammouti B: Electrochemical studies of new pyridazinium-based ionic liquid, (1-4-nitro phenyl-1-ethanone) pyridazinium bromide, on carbon steel corrosion in hydrochloric acid medium. Int J Electrochem Sci 10: 4532-4551, 2015.

8. Biswas A, Shogren RL, Stevenson DG, Willett JL and Bhowmik PK: Ionic liquids as solvents for biopolymers: Acylation of starch and zein protein. Carbohydr Polym 66: 546-550, 2006.

9. Talavera-Prieto NM, Ferreira AG, Simões PN, Carvalho PJ, Mattedi S and Coutinho JA: Thermophysical characterization of N-methyl-2-hydroxyethylammoniumcarboxilate ionic liquids. J Chem Thermodyn 68: 221-234, 2014.
10. Petkovic M, Ferguson J, Bohn A, Trindade J, Martins I, Carvalho MB, Leitão MC, Rodrigues C, Garcia H, Ferreira R, et al: Exploring fungal activity in the presence of ionic liquids. Green Chem 11: 889-894, 2009.

11. Iwai N, Nakayama K, Oku J and Kitazume T: Synthesis and antibacterial activity of alaremycin derivatives for the porphobilinogen synthase. Bioorg Med Chem Lett 21: 2812-2815, 2011.

12. Alberto EE, Rossato LL, Alves SH, Alves D and Braga AL: Imidazolium ionic liquids containing selenium: Synthesis and antimicrobial activity. Org Biomol Chem 9: 1001-1003, 2011.

13. Coleman D, Špulák M, Garcia MT and Gathergood N: Antimicrobial toxicity studies of ionic liquids leading to a 'hit' MRSA selective antibacterial imidazolium salt. Green Chem 14: 1350-1356, 2012.

14. Tavares AP, Rodriguez O, Raquel Cristóvão and Macedo EA: Applications and perspectives ionic liquids: Alterna-tive reactive media for oxidative enzymes. In: Ionic Liquids, Kokorin A (ed). Rijeka, InTech, pp449-516, 2011.

15. Rodríguez O, Cristovao, RO, Tavares APM and Macedo EA Study of the alkyl chain length on laccase stability and enzymatic kinetic with imidazolium ionic liquids. Biotechnol Appl Bioc 164: 524-533, 2011.

16. Cieniecka-Roslonkiewicz A, Pernak J, Kubis-Feder J, Ramani A, Robertson AJ and Seddo KR: Synthesis, anti-microbial activities and anti-electrostatic properties of phosphonium-based ionic liquids. Green Chem 7: 855-862, 2005.

17. Carson L, Chau PK, Earle MJ, Gilea MA, Gilmore BF, Gorman SP, McCann MT and Seddon KR: Antibiofilm activities of 1-alkyl-3-methylimidazolium chloride ionic liquids. Green Chem 11: 492-497, 2009.

18. Messali M: Eco-friendly synthesis of a new class of pyridinium-based ionic liquids with attractive antimicrobial activity. Molecules 20: 14936-14949, 2015.

19. Egorova KS, Gordeev EG and Ananikov VP: Biological activity of ionic liquids and their application in pharmaceutics and medicine. Chem Rev 117: 7132-7189, 2017.

20. Kapałczyńska M, Kolenda T, Przybyła W, Zajączkowska M, Teresiak A, Filas V, Ibbs M, Bliźniak R, Łuczewski L and Lamperska K: 2D and 3D cell cultures-a comparison of different types of cancer cell cultures. Arch Med Sci 14: 910-919, 2018.

21. CLSI. Performance standards for antimicrobial susceptibility testing. 27th edition. CLSI supplement M100. Wayne, PA: Clinical and Laboratory Standards Institute, 2017.

22. Kurnia KA, Sintra TE, Neves CM, Shimizu K, Canongia Lopes JN, Goncalves F, Ventura SP, Freire MG, Santos LM and Coutinho JA: The effect of the cation alkyl chain branching on mutual solubilities with water and toxicities. Phys Chem Chem Phys 16: 19952-19963, 2014.

23. Ohno H, Fujita $\mathrm{K}$ and Kohno Y: Is seven the minimum number of water molecules per ion pair for assured biological activity in ionic liquid-water mixtures? Phys Chem Chem Phys 17: 14454-14460, 2015.

24. Wang Y, Li H and Han SA: A theoretical investigation of the interactions between water molecules and ionic liquids. J Phys Chem B 110: 24646-24651, 2006.

25. Zheng Z, Xu Q, Guo J, Qin J, Mao H, Wang B and Yan F: Structure-antibacterial activity relationships of imidazolium-type ionic liquid monomers, poly(ionic liquids) and poly(ionic liquid) membranes: Effect of alkyl chain length and cations. ACS Appl Mater Interfaces 8: 12684-12692, 2016.

26. Khudyakov JI, D'Haeseleer P, Borglin SE, Deangelis KM, Woo H, Lindquist EA, Hazen TC, Simmons BA and Thelen MP: Global transcriptome response to ionic liquid by a tropical rain forest soil bacterium, Enterobacter lignolyticus. Proc Natl Acad Sci USA 109: E2173-E2182, 2012.

27. Borkowski A, Kowalczyk P, Czerwonka G, Cieśla J, Cłapa T, Misiewicz A, Szala M and Drabik M: Interaction of quaternary ammonium ionic liquids with bacterial membranes-studies with Escherichia coli r1-r4-type lipopolysaccharides. J Mol Liquids 246: 282-289, 2017.

28. Kowalczyk P, Borkowski A, Czerwonka G, Cłapa T, Cieśla J, Misiewicz A, Borowiec M and Szala M: The microbial toxicity of quaternary ammonium ionic liquids is dependent on the type of lipopolysaccharide. J Mol Liquids 266: 540-547, 2018.

29. Dauborca VC, Dumitrascu V, Popescu R, Cimporescu A, Vlad CS, Flangea C, Grecu DS, Vágvölgyi C, Papp T and Horhat FG: Gas chromatography-mass spectrometry evidences for new chemical insights of momordica charantia. Rev Chim 66: 1914-1920, 2015.

30. Moatar AE, Vlad CS, Vlad DC, Verdes DM, Filimon MN, Bloju O, Borcan F, Dehelean CA and Dumitrascu V: Evaluation of antiproliferative potential of Myrmecodia pendans and its activity on il-8 secretion in colon cancer cell. Farmacia 68: 710-714, 2020. 
31. O'Toole GA, Wathier M, Zegans ME, Shanks RM, Kowalski R and Grinstaff MW: Diphosphonium ionic liquids as broad-spectrum antimicrobial agents. Cornea 31: 810-816, 2012.

32. Hou XD, Liu QP, Smith TJ, Li N and Zong MH: Evaluation of toxicity and biodegradability of cholinium amino acids ionic liquids. PLoS One 8: e59145, 2013.

33. Docherty KM, Joyce MV, Kulacki KJ and Kulpa CF: Microbial biodegradation and metabolite toxicity of three pyridinium-based cation ionic liquids. Green Chem 12: 701-712, 2010.

34. Hough-Troutman WL, Smiglak M, Griffin S, Matthew Reichert W, Mirska I, Jodynis-Liebert J, Adamska T, Nawrot J, Stasiewicz M, Rogers RD and Pernak J: Ionic liquids with dual biological function: Sweet and anti-microbial, hydrophobic quaternary ammonium-based salts. New J Chem 33: 26-33, 2009.

35. Stoimenovski J, MacFarlane DR, Bica K and Rogers RD Crystalline vs. ionic liquid salt forms of active pharmaceutical ingredients: A position paper. Pharm Res 27: 521-526, 2010.

36. Tran CD, Prosenc F and Franko M: Facile synthesis, structure, biocompatibility and antimicrobial property of gold nanoparticle composites from cellulose and keratin. J Colloid Interface Sci 510: 237-245, 2018.

37. Gilmore BF: Antimicrobial ionic liquids, In: Ionic Liquids: Applications and Perspectives, Kokorin A (ed). InTech, Rijeka, pp587-604, 2011

38. Yu Y and Nie Y: Toxicity and antimicrobial activities of ionic liquids with halogen anion. J Environ Prot 2: 298-303, 2011.

39. Ventura SPM, Gurbisz M, Ghavre M,Ferreira FMM, Gonçalves F, Beadham I, Quilty B, Coutinho JAP and Gathergood N: Imidazolium and pyridinium ionic liquids from mandelic acid derivatives: Synthesis and bacteria and algae toxicity evaluation. ACS Sustain Chem Eng 1: 393-402, 2013.

40. Payagala T and Armstrong DW: Chiral ionic liquids: A compendium of syntheses and applications (2005-2012). Chirality 24 $17-53,2012$.

41. Haragus H, Vermesan D, Lazureanu V, Ferdean N, Radu D, Prejbeanu R and Niculescu M: Antibiotic loaded cement spacers for two stage treatment of periprosthetic joint infections. Rev Chim (Bucharest) 67: 764-767, 2016

42. Messali M, Aouad MR, El-Sayed WS, Ali AA, Ben Hadda T and Hammouti B: New eco-friendly 1-alkyl-3-(4-phenoxybutyl) imidazolium-based ionic liquids derivatives: A green ultrasound-assisted synthesis, characterization, antimicrobial activity and POM analyses. Molecules 19: 11741-11759, 2014.

43. Miskiewicz A, Ceranowicz P, Szymczak M, Bartuś K and Kowalczyk P: The use of liquids ionic fluids as pharmaceutically active substances helpful in combating nosocomial infections induced by Klebsiella pneumoniae New Delhi strain, Acinetobacter baumannii and Enterococcus species. Int J Mol Sci 19: 2779, 2018.
44. Egorova KS, Seitkalieva MM,Posvyatenko AV and Ananikov VP: An unexpected increase of toxicity of amino acid-containing ionic liquids. Toxicol Res 4: 152-159, 2015.

45. Frade RFM, Matias A, Branco LC, Afonsoc CAM and Duarte CMM: Effect of ionic liquids on human colon carcinoma HT-29 and CaCo-2 cell lines. Green Chem 9: 873-877, 2007.

46. Frade RFM, Rosatella AA, Marques CS, Branco LC, Kulkarni PS Mateus NMM, Afonso CAM and Duarte CMM: Toxicological evaluation on human colon carcinoma cell line $(\mathrm{CaCo}-2)$ of ionic liquids based on imidazolium, guanidinium, ammonium, phosphonium, pyridinium and pyrrolidinium cations. Green Chem 11: 1660-1665, 2009.

47. García-LorenzoA,TojoE,TojoJ,TeijeiraM,Rodríguez-BerrocalFJ, Pérez González M and Martínez-Zorzano VS: Cytotoxicity of selected imidazolium-derived ionic liquids in the human Caco-2 cell line. Sub-structural toxicological interpretation through a QSAR study. Green Chem 10: 508-516, 2008.

48. Kumar V and Malhotra SV: Study on the potential anti-cancer activity of phosphonium and ammonium-based ionic liquids. Bioorg Med Chem Lett 19: 4643-4646, 2009.

49. Li X, Ma J and Wang J: Cytotoxicity, oxidative stress, and apoptosis in HepG2 cells induced by ionic liquid 1-methyl3-octylimidazolium bromide. Ecotoxicol Environ Saf 120: 342-348, 2015.

50. Ranke J, Mölter K, Stock F, Bottin-Weber U, Poczobutt J, Hoffmann J, Ondruschka B, Filser J and Jastorff B: Biological effects of imidazolium ionic liquids with varying chain lengths in acute vibrio fischeri and WST-1 cell viability assays. Ecotoxicol Environ Saf 58: 396-404, 2004

51. Flieger $\mathrm{J}$ and Flieger $\mathrm{M}$ : Ionic liquids toxicity-benefits and threats. Int J Mol Sci 21: 6267, 2020.

52. Zakrewsky M, Lovejoy KS, Kern TL, Miller TE, Le V, Nagy A, Goumas AM, Iyer RS, Del Sesto RE, Koppisch AT, et al: Ionic liquids as a class of materials for transdermal delivery and pathogen neutralization. Proc Natl Acad Sci USA 111: 13313-13318, 2014.

53. Miwa Y, Hamamoto H, Hikake S and Kuwabara Y: A phase I, randomized, open-label, cross-over study of the pharmacokinetics, dermal tolerability, and safety of MRX-7EAT etodolac-lidocaine topical patch in healthy volunteers. J Pain 14 (Suppl 4): S72, 2013

This work is licensed under a Creative Commons Attribution-NonCommercial-NoDerivatives 4.0 International (CC BY-NC-ND 4.0) License. 